\title{
The Potential of Anting - Anting (Acalypha indica L.) Leaf Extract as Anti- Scabies to Sarcoptes scabiei var. Cuniculi in vitro
}

\section{Potensi Ekstrak Daun Anting-Anting (Acalypha indica L) sebagai Anti-Skabies terhadap Sarcoptes scabiei var. cuniculi secara in vitro}

\author{
${ }^{1)}$ Luluk Tri Astuti, ${ }^{2)}$ Rahmi Sugihartuti, ${ }^{3)}$ Lianny Nagoi, ${ }^{4}$ Nunuk Dyah Retno Lastuti, ${ }^{2)}$ Dewa \\ Ketut Meles, ${ }^{4)}$ Agus Sunarso \\ ${ }^{1)}$ Student, Faculty of Veterinary Medicine, Universitas Airlangga. \\ ${ }^{2)}$ Department of Basic Veterinary Medicine, Faculty of Veterinary Medicine, Universitas Airlangga. \\ 3) Department of Veterinary Clinic, Faculty of Veterinary Medicine, Universitas Airlangga. \\ 4) Department of Veterinary Parasitology, Faculty of Veterinary Medicine, Universitas Airlangga. \\ Received: 05-08-2019, Accepted: 12-08-2019, Published Online: 16-08-2019
}

\begin{abstract}
The Aim of research to determine the potential of anting-anting (Acalypha indica L.) leaf extract as anti-scabies to Sarcoptes scabiei var. Cuniculi in vitro by observing the mortality rates and lethal concentration of Sarcoptes scabiei. There were 5 treatments namely DMSO o.5\% (PN). Amitraz (Po), anting-anting (Acalypha indica L.) leaf extract concentratrion of $6,25 \%\left(\mathrm{P}_{1}\right), 12,5 \%\left(\mathrm{P}_{2}\right)$ and $25 \%\left(\mathrm{P}_{3}\right)$. Observations were carried out for 8 hours with stereomicroscope. The data was analyzed using rpobit analysis with SPSS 20.0 software. The results showed that the fastest mortality rate of S. Scabiei was group p3 at 4.6 mites/hour., then $\mathrm{Po}, \mathrm{P}_{2}, \mathrm{P}_{1}$ and $\mathrm{PN}$ respectively 3.5, 3.1, 1.9, and 1.3 mites/ hour. The smallest concentration of anting-anting (Acalypha indica L.) leaf extract was not significantly different compared to amitraz for killing of $50 \%$ and $90 \%$ S. Scabiei was $12.5 \%$ with lethal time $\left(\mathrm{LT}_{50}\right) 1.82$ hours and $\left(\mathrm{LT}_{90}\right) 3.69$ hours. In conclusion, anting-anting (Acalypha indica L.) leaf extract has mortality rate against S. Scabiei var. Cuniculi of 3.1 mites/hour, lethal concentration of $\mathbf{1 2 . 5} \%$ and potential as anti-scabies in vitro.
\end{abstract}

\section{Keywords : Acalypha indica L, anti-scabies, Sarcoptes scabiei, in vitro}

\section{Pendahuluan}

Skabies adalah penyakit kulit menular yang bersifat zoonosis dan disebabkan oleh tungau Sarcoptes scabiei (Wardhana dkk., 2006). Balai Penyidikan dan Pengujian Veteriner (BPPV) di Indonesia mencatat 535 kasus kejadian skabies pada ternak dan hewan kesayangan yang masih tinggi di Indonesia (Budiantono, dalam Wardhana dkk., 2006). Hasil penelitian di daerah Jambi menunjukkan tingkat kejadian skabies sebanyak $100 \%$ pada kambing (Rahayu, 2008). Hal ini menunjukkan bahwa tingginya kejadian skabies masih menjadi ancaman bagi hewan.

Pengobatan skabies selama ini menggunakan ivermectin, asuntol, neguvon yang sulit didapat dan harga relatif mahal (Iskandar, 200o). Selain itu, Currie dkk. (2004) membuktikan bahwa telah terjadi resistensi $S$. scabiei secara in vitro dan in vivo terhadap obat tersebut. Oleh karena itu diperlukan alternatif pengobatan skabies yang lebih murah dan mudah didapatkan. Salah satu alternatif pengobatan skabies yaitu menggunakan tanaman anting-anting (Acalypha indica L.). Daun anting-anting merupakan bagian yang paling banyak dimanfaatkan (64\%), diikuti batang (24\%) dan akar (12\%) (Zahidin dkk., 2017). Uji fitokimia tanaman anting-anting menunjukkan kandungan senyawa golongan flavonoid, triterpenoid, steroid dan saponin (Halimah, dalam Yasmin dkk., 2013) serta alkaloid (Mohan dkk., 2012).

Di bidang parasitologi daun anting-anting telah terbukti sebagai ovisida dan larvisida untuk Anopheles stephensi Liston (Kamalakannan dkk., 2010) serta pupisidal (Seebaluck, dkk., 2015). Penelitian ekstrak daun anting-anting sebagai anti-skabies belum pernah dilakukan, sehingga perlu dilakukan penelitian mengenai "Potensi ekstrak daun anting-anting (Acalypha indica L.) sebagai Antiskabies terhadap Sarcoptes scabiei var. cuniculi secara in vitro". 


\section{Metode}

Bahan dan sampel penelitian

Bahan yang digunakan dalam penelitian ini yaitu daun anting-anting, Etanol PA 96\%, larutan iodium (Betadine), larutan $\mathrm{KOH} 10 \%$, DMSO o, $5 \%$, aquadest steril, amitraz 12,5\% dan alkohol $76 \%$. Sampel yang digunakan dalam penelitian ini yaitu Sarcoptes scabiei var. cuniculi stadium dewasa.

\section{Metode Penelitian}

\section{Ekstraksi Daun Anting-anting}

Daun Anting-anting dikeringkan, lalu daun dihancurkan menggunakan blender hingga berbentuk simplisia. Kemudian di maserasi dengan etanol 96\% 1:5 (b:v) selama 10 menit. Ekstrak yang dihasilkan kemudian disaring menggunakan kertas saring (Farmakope Indonesia V, 2014). Selanjutnya dilakukan evaporasi menggunakan rotary evaporator pada suhu $40^{\circ} \mathrm{C}$ sampai diperoleh ekstrak kental lalu dilakukan pengeringan beku hingga terbentuk serbuk ekstrak daun antinganting.

\section{Pembuatan Ekstrak Daun Anting-anting}

Sediaan ekstrak daun anting-anting dibuat menjadi 3 konsentrasi yaitu 6,25\%, 12,5\% dan $25 \%$. Masing-masing konsentrasi ekstrak daun anting-anting dilarutkan dalam o,1 ml DMSO 0,5\% lalu dicampur. Setelah itu dimasukkan ke dalam botol dan ditambahkan aquadest steril sampai dengan tanda kalibrasi.

\section{Konfirmasi Hewan Coba}

Sampel yang digunakan dalam penelitian ini yaitu stadium dewasa $S$. scabiei var. cuniculi dari kelinci yang menunjukkan gejala klinis skabies. Menurut Lastuti dkk. (2018) gejala klinis skabies meliputi penebalan kulit, terdapat krusta, alopesia disekitar mata, telinga, mulut dan kaki.

\section{Koleksi, Isolasi dan Identifikasi Stadium Dewasa Sarcoptes scabiei}

Pertama kelinci di scraping pada area telinga dan kaki. Hasilnya dikumpulkan di cawan petri. Prosedur ini sudah melalui uji kelaikan etik No. 1.KE.128.07.2018 oleh Komisi Etik Penelitian Fakultas Kedokteran Hewan Universitas Airlangga Animal Care and Use Committee (ACUC). Koleksi dan isolasi dilakukan dengan menggunakan jarum (Walton dan Currie, 2007). Kemudian dibagi secara acak kedalam cawan petri, masing- masing terisi $20 \mathrm{~S}$. scabiei dengan 5 kali ulangan. Identifikasi stadium dewasa $S$. scabiei dilakukan berdasarkan morfologi $S$. scabiei (Taylor dkk., 2016).

Perendaman Sarcoptes scabiei dengan Ekstrak Daun Anting-Anting

Sarcoptes scabiei dibagi 5 kelompok perlakuan. Satu kelompok sebagai kontrol negatif direndam $1 \mathrm{ml}$ DMSO o,5\% (PN), satu kelompok sebagai kontrol positif direndam $1 \mathrm{ml}$ amitraz (Po), dan tiga kelompok direndam $1 \mathrm{ml}$ ekstrak daun anting-anting masing-masing konsentrasi $6,25 \%, 12,5 \%$ dan $25 \%$ ( $\mathrm{P}_{1}, \mathrm{P}_{2}$ dan $\left.\mathrm{P}_{3}\right)$. Kemudian diinkubasi pada suhu ruangan $\left(27^{\circ} \mathrm{C}\right)$.

\section{Pengamatan Kematian Sarcoptes scabiei}

Pengamatan kematian S. scabiei dilakukan setiap 15, 30, 45, 6o menit dilanjutkan setiap jam sekali selama 8 jam. Menurut Macchioni dkk. (2004) bahwa parameter kematian $S$. scabiei ditandai dengan tidak adanya reaksi atau pergerakan $S$. scabiei setelah distimulasi dengan jarum.

\section{Analisis data}

Data parametrik yang diperoleh dianalisis dengan analisis Probit menggunakan program SPSS versi 20.o (Nong, dkk., 2012).

\section{Hasil dan Pembahasan Koleksi Sarcoptes scabiei}

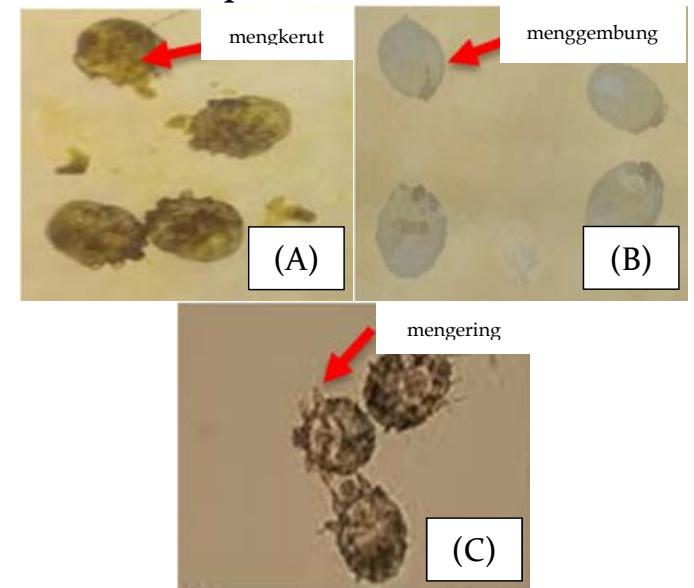

Gambar 1. Sarcoptes scabiei pasca perlakuan. (a) dengan ekstrak daun anting-anting (b) dengan amitraz (c) dengan DMSO.

Hasil isolasi stadium dewasa S. scabiei berbentuk bulat atau oval, cembung pada bagian punggung dan rata pada bagian perut serta berwarna transparan dan agak kehitaman. 
Perlakuan menggunakan ekstrak daun antinganting (Acalypha Indica L.) menunjukkan S. scabiei tidak bergerak, tubuh mengkerut dan rapuh, tubuh menjadi pipih, kering dan kaki menekuk (Gambar 1a). Hal ini diduga akibat kandungan saponin dan tanin yang terdapat dalam ekstrak daun anting-anting. Menurut Novizan (2002) menyebutkan bahwa pengaruh saponin terlihat pada gangguan fisik serangga bagian luar (kutikula), yaitu merusak lapisan lilin yang melindungi tubuh serangga dan menyebabkan kematian karena kehilangan banyak cairan tubuh. Sedangkan menurut Helathink (dalam Sukorini, 2006) tannin bekerja sebagai astringent, menyusutkan jaringan dan mendegradasi struktur protein pada kulit dan mukosa.

Perlakuan dengan amitraz menunjukkan S. scabiei tidak ada pergerakan, tubuh menggembung, baru setelah beberapa jam setelah kematian tubuhnya mengkerut (Gambar $1 b)$. Hal ini diduga karena pengaruh amitraz yang bersifat agonis terhadap reseptor oktopamin (OA) S. scabiei. Menurut Farooqui (2012) bahwa pengikatan OA dengan reseptor ini akan mengaktifkan enzim adenyl siklase yang mengubah ATP ke cAMP dan menyebabkan cAMP dan $\mathrm{Ca}^{2+}$ tingkat intraseluler meningkat. Akibatnya ATP mengalami penurunan maka mengakibatkan terjadinya gangguan sodiumpotassium pump membrane. Hal ini sesuai pendapat Arimbi dkk. (2013) bahwa penurunan ATP mengakibatkan terjadi gangguan sodiumpotasium pump membrane yang menyebabkan terjadi pergeseran ion membran. Sodium $\left(\mathrm{Na}^{+}\right)$ tertahan dalam sel sehingga sitoplasma lebih pekat, akibatnya menarik $\mathrm{H}_{2} \mathrm{O}$ dan kalsium $\left(\mathrm{Ca}^{2+}\right)$ masuk dalam sel secara meningkat, potassium $\left(\mathrm{K}^{+}\right)$dan magnesium $\left(\mathrm{Mg}^{2+}\right)$ bergerak keluar sel, sehingga terjadi perubahan cytoskeleton, bentuk sel berubah, terjadi pembengkakan sel secara akut (cell swelling).

Perlakuan dengan DMSO menunjukkan kematian S. scabiei normal yaitu tubuh mengkerut dan rapuh, tubuh menjadi pipih, kering dan kaki menekuk. Perbedaan dengan perlakuan ekstrak daun anting-anting menunjukkan morfologi $S$. scabiei yang tampak tidak utuh, sedangkan dengan DMSO morfologinya masih utuh.

\section{Kecepatan Kematian Sarcoptes scabiei}

Kecepatan kematian merupakan jumlah $S$. scabiei yang mati dalam satuan waktu yaitu per jam. Kecepatan mematikan S. scabiei ekstrak daun anting-anting konsentrasi $12,5 \%$ lebih lambat dibandingkan amitraz, namun secara statistik tidak terdapat perbedaan yang nyata (p>0.o1) (Tabel 1). Hal ini diduga ada persamaan mekanisme kerja keduanya yaitu mempengaruhi saraf $S$. scabiei. Ekstrak daun anting-anting dengan kandungan minyak esensial mampu mempengaruhi reseptor OA. Hal ini sesuai dengan pendapat Jankowska, dkk. (2017) bahwa minyak esensial memberikan efek terhadap reseptor OA, yang merupakan reseptor spesifik pada invertebrata termasuk $S$. scabiei dan menurut British Veterinary Association (2005) bahwa amitraz bekerja pada reseptor OA pada tungau yang akan meningkatkan aktivitas sistem saraf.

Tabel 1. Kecepatan kematian S. scabiei secara in vitro dengan analisis Probit

\begin{tabular}{|c|c|c|c|}
\hline $\begin{array}{l}\text { Perla } \\
\text { kuan }\end{array}$ & $\begin{array}{r}\text { Konsent } \\
\text { rasi }(\%)\end{array}$ & $\begin{array}{l}\text { Probit model } \\
(\mathrm{P})= \\
\text { intercept }+\mathrm{BX}\end{array}$ & $\begin{array}{c}\text { Kecepatan } \\
\text { kematian } \\
\text { (ekor/jam) }\end{array}$ \\
\hline PN & $\begin{array}{c}\text { DMSO } \\
0,5\end{array}$ & $\begin{array}{c}\mathrm{P}=-2.938+ \\
4.201 \mathrm{X}\end{array}$ & $1.3^{\mathrm{d}}$ \\
\hline $\mathrm{P}_{1}$ & $\begin{array}{c}\text { Ekstrak } \\
25\end{array}$ & $\begin{array}{c}\mathrm{P}=0.399 \\
4.201 \mathrm{X}\end{array}+$ & $4.6^{\mathrm{a}}$ \\
\hline $\mathrm{P}_{2}$ & $\begin{array}{c}\text { Ekstrak } \\
12,5\end{array}$ & $\begin{array}{c}\mathrm{P}=-1.090+ \\
4.201 \mathrm{X}\end{array}$ & $3.1^{\mathrm{b}}$ \\
\hline $\mathrm{P}_{3}$ & $\begin{array}{c}\text { Ekstrak } \\
6,25\end{array}$ & $\begin{array}{c}\mathrm{P}=-2.251+ \\
4.201 \mathrm{X}\end{array}$ & $1.9^{c}$ \\
\hline Po & $\begin{array}{l}\text { Amitra } \\
\mathrm{z} \mathrm{12,5}\end{array}$ & $\begin{array}{c}\mathrm{P}=0.730+ \\
4.201 \mathrm{X}\end{array}$ & $3 \cdot 5^{\mathrm{b}}$ \\
\hline
\end{tabular}

Superskrip yang berbeda pada kolom yang sama menunjukkan berbeda nyata $(\mathrm{p}<\mathrm{o}, \mathrm{ol})$

Keterangan : $\mathrm{B}=$ Waktu rata-rata

\section{Letal Konsentrasi Ekstrak Daun Anting-} Anting (Acalypha Indica L.)

Letal konsentrasi ekstrak daun antinganting merupakan konsentrasi terkecil ekstrak daun anting-anting yang sudah mampu menimbulkan kematian 50\% maupun 90\% total populasi. Tabel 3 menunjukkan bahwa ekstrak daun anting-anting konsentrasi $12,5 \%$ merupakan konsentrasi terkecil pada perlakuan jika dibandingkan amitraz dengan letal waktu $\left(\mathrm{LT}_{50}\right)$ dan $\left(\mathrm{LT}_{90}\right)$ sebesar 1.82 dan $3.69 \mathrm{jam}$. Kematian S. scabiei tersebut diduga disebabkan komponen farmakologis berupa saponin, glikosid dan minyak esensial yang terkandung dalam ekstrak daun anting-anting. Menurut Pavela (2016) dan Kosgei, dkk. (2017) bahwa saponin mempunyai aktivitas acaricidal termasuk anti-skabies. Hal ini karena saponin mampu menurunkan tegangan permukaan selaput mukosa sistem pencernaan serangga 
sehingga dindingnya menjadi korosif dan akhirnya rusak (Dinata, 2008). Mekanisme ini mengakibatkan S. scabiei akan mati karena sudah tidak mampu mencerna makanan sehingga kelaparan kemudian lemah dan akhirnya mati.

Tabel 3. Letal waktu $\left(\mathrm{LT}_{50}\right)$ dan $\left(\mathrm{LT}_{90}\right)$ ekstrak daun anting-anting (Acalypha Indica L.) dalam konsentrasi yang berbeda untuk mematikan $S$. scabiei

\begin{tabular}{cccc}
\hline Perlakuan & $\begin{array}{c}\text { Konsentrasi } \\
(\%)\end{array}$ & $\begin{array}{c}\mathrm{LT}_{50} \\
(\mathrm{Jam})\end{array}$ & $\begin{array}{c}\mathrm{LT}_{9 \mathrm{o}} \\
(\mathrm{Jam})\end{array}$ \\
\hline PN & DMSO o,5 & $5.00 \pm$ & $10.1 \pm$ \\
& & $1.211^{\mathrm{d}}$ & $2.558^{\mathrm{d}}$ \\
P1 & Ekstrak 25 & $0.80 \pm$ & $1.62 \pm$ \\
& & $0.211^{\mathrm{a}}$ & $0.453^{\mathrm{a}}$ \\
P2 & Ekstrak 12,5 & $1.82 \pm$ & $3.69 \pm$ \\
& & $0.516^{\mathrm{b}}$ & $1.053^{\mathrm{b}}$ \\
P3 & Ekstrak 6,25 & $3.44 \pm$ & $6.93 \pm$ \\
& & $0.852^{\mathrm{c}}$ & $1.684^{\mathrm{c}}$ \\
Po & Amitraz 12,5 & $1.49 \pm$ & $3.02 \pm$ \\
& & $0.432^{\mathrm{b}}$ & $0.874^{\mathrm{b}}$ \\
\hline
\end{tabular}

PN $=$ Kontrol Negatif dengan DMSO o, $5 \%, \mathrm{P} 1=$ Perlakuan dengan ekstrak daun anting-anting konsentrasi 25\%, $\mathrm{P}_{2}=$ Perlakuan dengan ekstrak daun anting-anting konsentrasi $12,5 \%$, $\mathrm{P}_{3}=$ Perlakuan dengan ekstrak daun antinganting konsentrasi 6,25\%, Po = Kontrol Positif dengan Amitraz 12,5\%. Superskrip yang berbeda pada kolom yang sama menunjukkan berbeda nyata $(\mathrm{p}<\mathrm{o}, \mathrm{ol})$.

Selain itu, beberapa penelitian menunjukkan bahwa minyak esensial mempunyai efek neurotoksik terhadap parasit dengan target molekuler yaitu enzim asetilkolinesterase (AChE), reseptor GABA ionotropik dan reseptor oktopamin metabotropik (Jankowska dkk., 2017). Arlian dkk. (2016) menyatakan bahwa $S$. scabiei mempunyai neurotransmitter yaitu asetilkolin, nikotinik, dopamin, serotonin, GABA dan neuropeptide $\gamma$. Hal ini menunjukkan adanya kesamaan antara target molekuler minyak esensial dan neurotransmitter $S$. scabiei yaitu enzim asetilkolinesterase dan reseptor GABA.

Menurut Arlian dkk. (2016) minyak esensial berpotensi sebagai sumber insektisida karena mampu memodifikasi aktivitas AChE (Seo dkk., 2014). Penghambatan AChE menyebabkan akumulasi asetilkolin sehingga terjadi disfungsi beberapa sistem saraf dan perilaku serta dapat memicu kerusakan pada sistem pernafasan serta akhirnya menyebabkan kematian (Touvinen dkk., 1994). Penelitian tentang mekanisme pengikatan minyak esensial pada GABArs belum diketahui secara mendalam (Bakkali dkk., 2008). Bukti paling jelas menyangkut efek minyak esensial yaitu pada reseptor OA, yang spesifik untuk invertebrata termasuk S. scabiei (Jankowska dkk., 2017). Minyak esensial bertindak terutama sebagai agonis terhadap reseptor OA dan Tiramin (TA) (Grifman dkk., 1997). Minyak esensial menyebabkan peningkatan baik pada cAMP dan $\mathrm{Ca}^{2+}$ tingkat intraseluler. Akibatnya apabila konsentrasi minyak esensial tinggi maka efek depresi serangga meningkat karena pengaruh rusaknya membran neuron (Price dan Berry 2006).

\section{Potensi Ekstrak Daun Anting-Anting} (Acalypha Indica L.) sebagai Anti-skabies

Potensi ekstrak daun anting-anting (Acalypha indica L.) secara in vitro yaitu kemampuan ekstrak daun anting-anting (Acalypha indica L.) untuk mematikan 50\% dan $90 \%$ S. scabiei diluar tubuh inangnya dengan melihat letal konsentrasi dan letal waktu ekstrak daun anting-anting. Ekstrak daun anting-anting konsentrasi $12,5 \%$ dan amitraz 12,5\% menunjukkan bahwa keduanya mempunyai kemampuan untuk mematikan $S$. scabiei yang sama.

Penelitian yang dilakukan oleh Govindarajan dkk. (2008) menunjukkan bahwa ekstrak daun anting-anting mempunyai $\mathrm{LC}_{50}-24$ jam sebesar 19,25 ppm, $27.76 \mathrm{ppm}, 23,26 \mathrm{ppm}$ dan 15,03 ppm dengan pelarut yang berbeda sebagai larvasidal dan ovisidal terhadap Anopheles stephensi. Selain itu, penelitian yang dilakukan oleh Kamalakannan, dkk. (2010) menunjukkan bahwa ekstrak daun anting-anting mempunyai nilai $\mathrm{LC}_{50^{-120}}$ jam sebesar $326 \mathrm{ppm}, 456 \mathrm{ppm}$ dan 467ppm terhadap kepompong Anopheles stephensi. Hal ini menunjukkan bahwa ekstrak daun anting-anting berpotensi digunakan sebagai anti-skabies. Hal ini didukung penelitian Gurib-Fakim (2011) bahwa mandi dengan ramuan daun anting-anting mampu melawan skabies.

\section{Kesimpulan}

Berdasarkan penelitian yang dilakukan dapat disimpulkan bahwa ekstrak daun antinganting (Acalypha Indica L.) mempunyai Kecepatan kematian Sarcoptes scabiei var. cuniculi secara in vitro sebesar 3.1 ekor/jam, Letal konsentrasi sebagai anti-skabies terhadap 
Sarcoptes scabiei var. cuniculi secara in vitro sebesar 12,5\% dan Berpotensi sebagai antiskabies terhadap Sarcoptes scabiei var. cuniculi secara in vitro.

\section{Daftar Pustaka}

Arimbi, A. Azmijah, R. Darsono, H. Plumeriastuti, T. V. Widiyatno, dan D. Legowo. 2013. Buku Ajar Patologi Umum Veteriner. ${ }^{\text {th }}$. ed. Hal. 15.

Arlian, L.G., M.S. Morgan and S. D. Rider Jr. 2016. Sarcoptes scabiei: Genomics to Proteomics to Biology. Parasites and Vectors. 9(380):1-13.

Bakkali, F., S. Averbeck, D. Averbeck and M. Idaomar. 2008. Biological Effects of Essential Oils - A review. Elsevier. Food and Chemical Toxicology .46: 446-475.

[BVA] British Veterinary Association. 2005. The Veterinary Formulary Sixth Edition. Yolande Bishop : Editor. London : Pharmaceutical Press.

Currie, B.J ., P. Harumal, M. Mckinnon and S.F. Walton. 2004. First Document of in vivo and in vitro Ivermectin Resistance in Sarcoptes scabiei. CID. 39:98- 112.

Dinata, A. 2008. Pemberantasan Penyakit Bersumber Binatang. http://www.litbang.depkes.go.id/lokaciamis/artikel/nyamukarda.htm.[6 November 2018]

Farooqui, T. 2012. Review of Octopamine in Insect Nervous Systems. Insect Physiol. $4: 1-17$.

Grifman, M., A. Arbel, D. Ginzberg, D. Glick, S. Elgavish, B. Shaanan and H. Soreq.1997. In vitro Phosphorylation of Acetylcholinesterase at Non-Consensus Protein Kinase a Sites Enhances The Rate of Acetylcholine Hydrolysis. Elsevier. Brain Res. Mol. Brain Res. 51: 179-187.

Govindarajan, M., A. Jebanesan, T. Pushpanathan and K. Samidurai. 2008. Studies on effect of Acalypha indica L. (Euphorbiaceae) leaf extracts on the malarial vector, Anopheles stephensi Liston (Diptera:Culicidae). Parasitol Res. 103:691-695.

Gurib-Fakim, A. 2011. Medicinal Plants of Mauritius and of the World. Caractère Ltèe, Mauritius.
Iskandar,T. 20oo. Masalah Skabies pada Hewan dan Manusia serta Penanggunalangannya. Wartazoa. 10(1): 28-34.

Jankowska, M., J. Rogalska, J. Wyszkowska and M. Stankiewicz. 2017. Molecular Targets for Components of Essential Oils in the Insect Nervous System-A Review. Elsevier. Molecules. 23(34): 1-20.

Kamalakannan, S., K. Murugan and D.R. Barnard. 2011. Toxicity of Acalypha indica (Euphorbiaceae) and Achyranthes aspera (Amaranthaceae) Leaf Extracts to Aedes aegypti (Diptera: Culicidae). Elsevier. J. Asia-Pac. Entomol. 14:41-45.

Kemenkes RI. 2014. Farmakope Indonesia. $5^{\text {th }}$. ed. Jakarta: Kementerian Kesehatan Republik Indonesia. Hal. 42.

Kosgei, C. J., C. M. Mwendia and J. C. Matasyoh. 2017. Phytochemical Analysis, Cytotoxicity Activity and Acaricidal Activity of Aqueous Crude Extract of Phytolacca dodecandra Against Larvae of Rhipicephalus appendiculatus. IOSR Journal of Pharmacy and Biological Sciences (IOSR-JPBS). 12(6):54-58.

Lastuti, N. D. R., P. Hastutiek, L.T. Suwanti and D. Chrismanto. 2018. Exploration of Sarcoptes scabiei Antigenic Protein Which Play Roles in Scabies Pathogenesis in Goats and Rabbits. Iran J Parasitol. $13(3): 466-472$.

Macchioni, F., S. Perrucci, F. Cecchi, P.L. Cioni, I. Morelli and S. Pampiglione. 2004. Acaricidal Activity of Aqueous Extracts of Chamomile Flowers, Matricaria chamo milla, Against The Mite Psoroptes cuniculi. Med. Vet. Entomol. 18: 205-207.

Mohan, C., S. Dinakar, T. Anand, R. Elayaraja and B. Sathiya Priya. 2012. Phytochemical, GC-MS Analysis and Antibacterial Activity of A Medicinal Plant Acalypha indica. Int. J. Pharm. Tech. Res. 4: 1050-1054.

Nong, Xiang, Yong-Jun Ren, Jia-Hai Wang, Yue Xie, Chun-Lin Fang, De-Ying Yang, TianFei Liu, Run-Hui Zhang, Lin Chen, XiaoBXue-Rong Peng,Shu-Xian Wang, Song-Jia Lai, Guang-You Yang, 2012. Acaricidal activity of extract from Eupatorium adenophorum againts the Psoroptes cuniculi and Sarcoptes scabiei in vitro. Elsevier. Veterinary Parasitology. 187: 345349 . 
Novizan. 2002. Membuat dan Memanfaatkan Pestisida Ramah Lingkungan. Jakarta: Agromedia Pustaka.

Panter, K.E. 2005. Natural toxins of plant origin. In: Dabrowski, W.M., Sikorski, Z.E. (Eds.), Toxin in Foods. CRC Press, Boca Raton, FL.11-63.

Pavela, R., 2016. Acaricidal Properties of Extracts of Some Medicinal and Culinary Plants against Tetranycus urticae Koch.. Plants Protect Sci. 53(1): 54-63.

Price, D.N. and M.S. Berry. 2006. Comparison of Effects of Octopamine and Insecticidal Essential Oils on Activity in The Nerve Cord, Foregut, and Dorsal Unpaired Median Neurons of Cockroaches. Elsevier. J. Insect Physiol. 52, 309-319.

Rahayu, P. 2008. Inventarisasi Kejadian Penyakit pada Ternak Kambing Bantuan Pemerintah di Desa Petaling Jaya, Kecamatan Kumpeh Ulu, Kabupaten Muaro Jambi Propinsi Jambi. Jurnal Ilmiah Ilmu-ilmu Peternakan. 11(4): 65-68.

Seebaluck, R., A. Gurib-Fakim and F. Mahomoodally. 2015. Medicinal Plants from The Genus Acalypha (Euphorbiaceae)-A Review of Their Ethno pharma cology and Phytochemistry. Elsevier. J. Ethnopharmacol. 159: 137-157.

Seo, S.M., J. Kim, J.S. Kang, S.H. Koh, Y.J. Ahn, K.S. Kang and I.K. Park. 2014. Fumigant Toxicity and Acetylcholinesterase
Inhibitory Activity of 4 Asteraceae Plant Essential Oils and Their Constituents Against Japanese Termite (Reticulitermes Speratus Kolbe). Elsevier. Pestic. Biochem. Physiol. 113: 55-61.

Sukorini, h. 2006. Pengaruh Pestisida Organik dan Interval Penyemprotan terhadap Hama Plutella xylostella pada Budidaya Tanaman Kubis Organik. Gamma, 2(1).

Taylor, M.A., R.L. Coop and R.L Wall. 2016. Veterinary Parasitology. $4^{\text {th }}$. ed. Oxford: Blackwell Publishing. 221.

Touvinen, K.,E. Kaliste-Korhonen, F.M. Raushel and O. Hanninen. 1994. Phosphotriesterase-A Promising Candidate for Use in Detoxification of Organophosphates. Fundam. Appl. Toxico,. 23: 578-584.

Walton, S.F. and B.J Currie. 2007. Problems in Diagnosing Scabies, A Global Disease in Human and Animal Populations. Clin. Microbiol. Rev. 20: 268-279.

Wardhana, A. H., J. Manurung dan T. Iskandar, 2006. Skabies Tantangan Penyakit Zoonosis Masa Kini dan Masa Datang. Wartazoa. 16(1): 40-52.

Zahidin, N. S., S. Saidina, R. M. Zulkiflia and I. I. Muhamad. 2017. A Review of Acalypha indica L. (Euphorbiaceae) as Traditional Medicinal Plant and Its Therapeutic Potential. Elsevier. Journal of Ethnopharmacology. 207:146-173. 